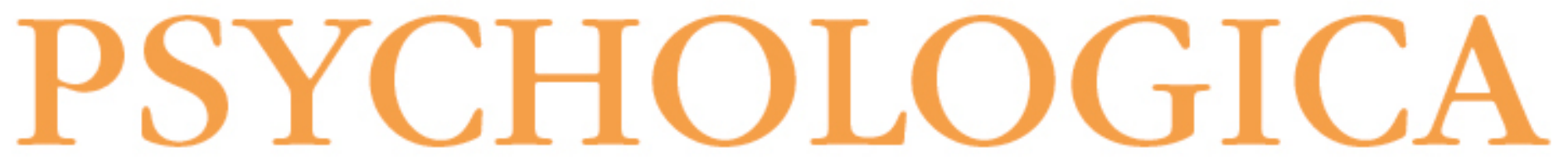

Reconstructing autobiographical memories for the present: objectification, anchoring, generational effect and social contexts

Autor(es): Madoglou, Anna

Publicado por: Imprensa da Universidade de Coimbra

URL

persistente: URI:http://hdl.handle.net/10316.2/3487

DOI: DOl:http://dx.doi.org/10.14195/1647-8606_52-2_26

Accessed : $\quad$ 26-Apr-2023 11:57:24

A navegação consulta e descarregamento dos títulos inseridos nas Bibliotecas Digitais UC Digitalis, UC Pombalina e UC Impactum, pressupõem a aceitação plena e sem reservas dos Termos e Condições de Uso destas Bibliotecas Digitais, disponíveis em https://digitalis.uc.pt/pt-pt/termos.

Conforme exposto nos referidos Termos e Condições de Uso, o descarregamento de títulos de acesso restrito requer uma licença válida de autorização devendo o utilizador aceder ao(s) documento(s) a partir de um endereço de IP da instituição detentora da supramencionada licença.

Ao utilizador é apenas permitido o descarregamento para uso pessoal, pelo que o emprego do(s) título(s) descarregado(s) para outro fim, designadamente comercial, carece de autorização do respetivo autor ou editor da obra.

Na medida em que todas as obras da UC Digitalis se encontram protegidas pelo Código do Direito de Autor e Direitos Conexos e demais legislação aplicável, toda a cópia, parcial ou total, deste documento, nos casos em que é legalmente admitida, deverá conter ou fazer-se acompanhar por este aviso.

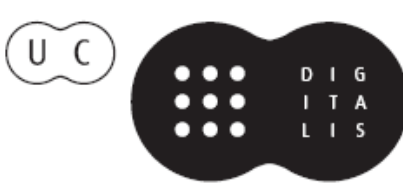




\section{NÚMERO 52}

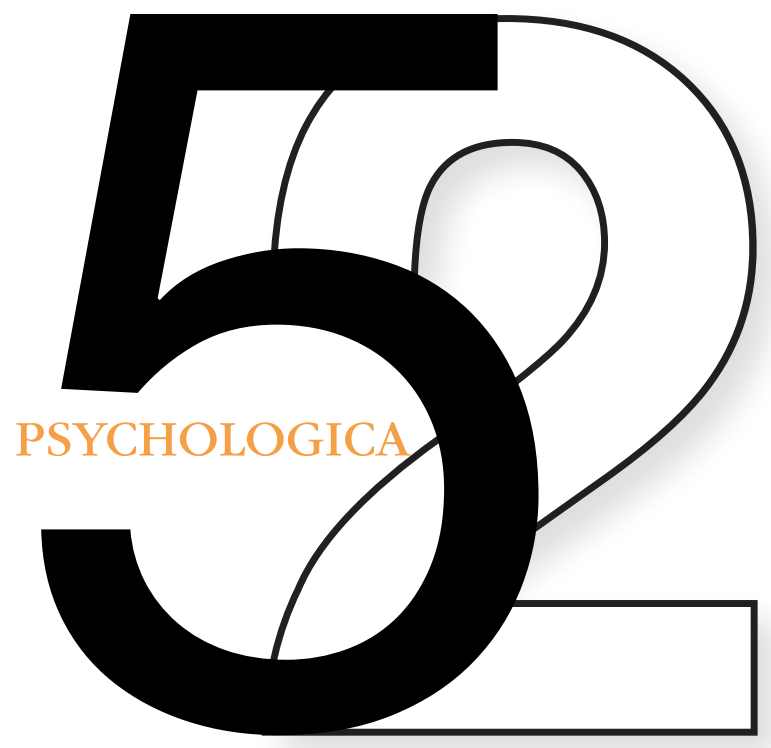

VOLUME II

IMPRENSA DA UNIVERSIDADE DE COIMBRA

FACULDADE DE PSICOLOGIA E DE CIÊNCIAS DA EDUCAÇÃo DA UNIVERSIDADE DE COIMBRA 


\title{
Reconstructing autobiographical memories for the present: Objectification, anchoring, generational effect and social contexts
}

\begin{abstract}
Anna Madoglou'
The present study examines the representational content of voluntary and involuntary autobiographical memories (objectification), as well as the anchorings according to age, sex and time contexts. 1.200 individuals of both sexes and different ages participated in this study and were asked to write down three memory events and three "oblivion" events in a personal, family and social framework and to note the date that these events took place. The results highlight the significance of social contexts in the reconstruction of the autobiographical past, which are space, time and different affiliation groups. The content of autobiographical memory is constructed through everyday relationships between the individuals and the members of the groups they belong to. Family, school, friends, the workspace, the socio-historical and political framework of their era provide the individuals with identity references. Both the quality and the time reference of the events depend on the age of the participants.
\end{abstract}

KEY-WORDS: Autobiographical Memory, Social memory and social oblivion, Social representations, Social contexts, Generational effect.

\section{Introduction}

The aim of the present study was to examine personal, family and social events people would like to remember or would rather forget, in order to identify what, why and through which processes people deliberately choose to remember or intentionally forget. Intentional forgetting of events, although not studied, as an on-line process per se in the present context, is also a form of remembering, albeit involuntary; along with its voluntary counterpart involuntary remembering supplies autobiographical memory with its contents. Autobiographical memory can be furthermore distinguished into "personal", "family" and "social" depending on the individual, interpersonal or social nature of the experienced event (Mado-

1 Professor of Social Psychology - Department of Psychology - Panteion University of Social and Political Science - madoglou@gmail.com 
glou, 2011). Personal memory includes events that have been mostly experienced individually, even though interpersonal in nature, and belong to the subject's more private personal life. Family memory comprises experiences resulting from family interactions and events individuals have shared with their family. Personal and family autobiographical memories are usually based on events directly experienced by the individual. Social memories however, represent general social knowledge about events, which is filtered by the personally internalized socially dominant system of norms and values.

Thus, the distinction among the different kinds of voluntary and involuntary autobiographical memories can have both a theoretical and a functional significance. On the one hand, it provides us with a better descriptive understanding of the possible structure of autobiographical memory contents and on the other hand, it helps us appreciate some of its functions. For example, research has indicated that an individual that has experienced rape is less likely to acknowledge it among personal events of involuntary remembering or forgetfulness and more likely to mention it in general as an event that a generalized other would rather forget (Madoglou, 2005; Madoglou, 2008).

It has long been argued that memory is selective. Some events will be retained whereas others will gradually be put aside and wane (Todorov, 2004). Selection of memory traces is not random but purposeful aiming at securing individual and social identity for present and future time. Voluntary memory contents contain events enhancing individual identity, while the ones of involuntary memory comprise events threateting it (Candau, 1998; Haas \& Jodelet, 1999). It is then important in studying memory to not only concentrate on what people do know but also on what they know that they "should not know". Remembering and forgetting are both human strategies.

In the subsequent sections we will first define the concepts of social autobiographical remembering and forgetting; we will then describe how they relate to the notion of social representations and illustrate the functions they serve. Finally, we will discuss the relationship of autobiographical memories with the so called "generational effect" and the social contexts of their construction.

\section{Autobiographical memories}

Autobiographical memory, although social in essence, can be seen as a set of past events (negative or positive) which significantly defined the individual. Auriat (1996) defines autobiographical memory as the recollection of self-defining personal past events, whereas Piolino, Desgranges \& Eustache (2000) describe 
it as the set of the particular information and remembrances the individual accumulates since childhood allowing him/her to construct a sense of identity and continuity. Hence, autobiographical memory is about experiences of actual personal events involved in the construction of individual identity. In that sense, autobiographical memories hardly ever cross the threshold of the family circle, the neighbourhood, the school, the friends and peers and the work-place; they are personal testimonies of events directly experienced by the individuals themselves; they have not reached the individuals indirectly, as information or third party accounts (Halbwachs, 1950/1968).

That said, it should also be emphasized that despite the fact that we have lived through each event individually and witnessed it personally, in reality we had never been alone and we are never alone (Halbwachs, 1950/1968); individuals are also members of groups (school, family, peers...) and in that sense autobiographical memories are social; defining them as personal is in part deceptive as our memories are created by interacting with others and depends on others, while at the same time it always occurs within a broader social context.

As already mentioned, memory is selective. No matter how important it is to examine the elements that have been selected to be retained in memory or those elements that are not to be forgotten, it is equally important to study those elements that have passed into social forgetfulness or have been identified as ones that should not be remembered. Memory functions as a filter of past events and contributes to the maintenance of images enhancing a positive social identity in the present. This suggests that we are not willing to preserve for the future a harmful legacy. Self-identity maintenance requires that painful and traumatic experiences that have already been censored, hidden or silenced, be removed from memory (Candau, 1998).

Public opinion usually contrasts social remembering to social forgetfulness, placing a positive value on the former and, explicitly or implicitly, a negative one on the latter (Rousso, 1999). We know, since the time of Freud that pleasant memories are preserved whereas painful ones are suppressed or repressed. Positive personal events are communicated and shared among individuals, while negative, unpleasant or traumatic events are kept in silence. Events of the past, are being selected, modified and transformed on the basis of people's current interests, the prevailing values and the pressing conditions of their time. People learn to forget; this skill they employ on specific events. Research (Madoglou, 2008) has suggested that autobiographical forgetting entails negative and distressful events such as being overwhelmed and defeated, deceived and betrayed, traumatic events that the individual wishes to forget. 
Past events are reconstructed and remulded in order to formulate cohesive memory. We commit to memory events that we wish to relate and pass on to others during communication. However, we also retain in memory indifferent events as well as worrisome and offensive ones. Such events are neither discussed nor recounted; they are passed over in silence. The study of forgotten experiences, although challenging, is rather difficult to achieve. It has been suggested that "silenced memories" are linked to events with negative social consequences, such as shameful or traumatic events that people don't want to disclose, probably concerning experiences people are unwilling to face (McLean, Pasupathi \& Pals, 2007). When people wish to recall or forget something, they use strategies. Research on the strategies of remembering and forgetting that people mention using (Madoglou, 2008, 2009) has indicated that the first are external (communication, mementoes, reminders, notes, photographs, monuments ...) whereas the second ones are internal (indifference, repression, rationalization, devaluation or playing down the importance of an event, recasting of meaning, plain rejection, avoidance, silence...). On the basis of these strategies, social subjects secure the construction of a trouble-free and beneficial for their identity past.

\section{Social memory and social representations}

Social memories have been conceptualized as a network of social representations regarding the past that individuals or the groups produce, maintain and transmit through communication during social interactions (Jodelet, 1992; Haas \& Jodelet, 2000; Deschamps, Paèz \& Pennebaker, 2001, 2002; Madoglou, 2005, 2010). Among social psychologists, social interaction is considered of crucial importance in shaping the content and functions of memories (McLean, Pasupathi \& Pals, 2007). Memory and representations are associated by means of processes that jointly re-construct and create social reality at a social-symbolic level. They are both related to individual and collective thought and functioning (Roussiau \& Bonardi, 2002). The two constructions share common characteristics:

a) Memories and representations turn "absence" into "presence", that is to say an event that has ceased to exist into an event of virtual existence in the milieu of reflection (Janet, 1928), whereas the representation of an object may be viewed as its "re-presentation" i.e., the re-appearance in present time of an absent object (Viaud, 2003);

b) Both memories and representations are constructed within the framework of communication and social interaction processes (Moscovici, 1976; Farr, 1984; Middleton \& Edwards; 1997; Haas \& Jodelet, 1999); 
c) Social representations are constructed by means of the processes of objectification and anchoring, both of which depend on memory (Moscovici, 1976). It could be argued that social representations are actually "controlled by memory" (Moscovici, 1981, p. 189), as they are made up on the basis of previous knowledge (Rouquette, 1997). These two complementary processes on the one hand exemplify the relationship of the represented object to the past and on the other hand mediate its social and historical relevance to the present.

d) Memories and representations maintain a dialectical relation: representations filter information and knowledge that is committed to memory, whereas the latter influences the content of representations themselves (Roussiau \& Bonardi, 2002);

e) Social representations are related to social memory only insofar as the latter constitutes the central core of the former (Abric, 1994; Abric \& Guimelli, 1998);

f) Social representations are defined as principles that organize the social relationships and the symbolic positions of social subjects. The organizational principles are stored in memory and obey the dominant normative, regulatory and symbolic thought (Doise, 1989). We inherit organizational principles and we evolve them within the framework of individual or group stories.

According to Doise (2009), there are three stages in the study of social representations (or social memory in our case). The first stage is the approach of the knowledge field shared by individuals (objectification). The second stage concerns the study of organizational principles of the positions taken by individuals. As far as the third stage is concerned, it has to do with the bonds between these positions and the special inscriptions of the individuals to other relational systems (anchoring).

\section{Autobiographical memory functions: identity construction}

As already mentioned, memory contents are not homogeneous and shared for all social subjects (individuals or groups). Hence, it would be more accurate to refer to memories (plural) rather than memory (Haas \& Jodelet, 1999; Thadden, 1999; Licata, Klain \& Gely, 2007). The content of memories depends on the social subjects' identity. "Identity" refers to the representation we hold for the self (self-image) and the one others hold for it (other's image of self or hetero-image). Lipiansky (1992) distinguishes individual from social identity. The former, involves "being conscious of the self as a separate stable and relatively cohesive individuality", whereas the latter is related to "being self-classified into bio-psychological categories (gender, age), socio-cultural groups (national and ethnic, local, professional...) 
or ideological orientations (religious, political, philosophical..." (p. 114 and 116). At any rate, individuals pursue the acquisition and maintenance of a positive selfidentity as it promotes self-enhancement and the preservation of self-esteem.

Following the self-identity theory (Camilleri, Kastersztein, Lipiansky et al., 1990), 604 there are strategies which the social subject may employ in order to maintain intra-individual or intra-group cohesion and secure positive bias for the self or favouritism toward his/her own group. Within this framework, memory works as a mechanism that selectively encodes the past, thereby contributing to identity formation. In other words, memory filters past events, aiming at retaining those supporting the continuity and cohesion of the social subject (Halbwachs, 1950/1968; Laurens \& Roussiau, 2002).

It has been suggested that one of the primary functions of autobiographical memory is to maintain and enhance the self-concept. Personal and social memories define who we are, enable us to construct our identities (Lyons, 1996) and shape self-development (McLean, Pasupathi, \& Pals, 2007), it keeps the person in touch with his or her roots and points to her or his future. Thus, we suggest that the content of autobiographical memory comprises events marking a change in self-concept (positive events for voluntary and negative events for involuntary memories) or conducive to the enhancement of the self-concept (positive voluntary memories). At the same time, it possesses a normative function which delineates desirable from undesirable actions (Licata, Klein \& Gely, 2007). The recollection of the personal sense of victory or defeat in one's own past actions and past deeds, deemed as moral or immoral, are a part of the whole process of defining one's own identity value. Additionally, whatever is recollected is determined by the contents of the specific individual or social identity, since identity determines what individuals remember, forget or hush up from the past.

Individuals belong to groups having a past, a history. Values, beliefs and the ideological system of their in-groups and more generally their ideological positions orient the content of past social representations towards effective communication and maintenance of intra-individual, inter-individual, intra-group, inter-group and ideological cohesion and integrity in the present as well as in the future. This is essentially a process leading to the construction of a positive and cohesive self-perception that claims to be firmly established at the level of others' perception of self. Consequently, memories and identities maintain a two-way, dialectical relationship: memories construct identities and identities construct memories (Candau, 1998, p. 6). 


\section{Social memory, social contexts and generational effect}

A basic prerequisite of the individual and social memory are the social contexts within which they are organized, allowing the reconstruction of the past on the basis of the meanings of the present situation and dominant thoughts (Jaisson, 1999). According to Halbwachs (1925/1994), time, space and language make up the framework of social memory and facilitate individuals to move backward through their past in order to identify and retrieve their recollections. The dimension of space can be located in the areas and fields in which the individual evolves and acts, as family, school, the workplace and their class, political, religious and national identity. Space, besides the fact that it orients recall, seems to be also influenced by the present and is characterized by the values, desires and preferences deriving from social factors. As far as time is concerned, it is not perceived merely as a calendar or a watch. It is transformed into a story of events which mark the lives of the individual, the group or the society, and is incorporated in memory as it offers links between the past, the present and the future. Finally, language, allows the externalization of human memory. It is the place where people think together, while its social use contributes in constructing the past.

Social memory's content is delineated by one's generation (Mannheim, 1928/1990; Schuman \& Scott, 1989; Olick, 1999; Madoglou, 2005, 2010). Generation, according to Mannheim, is set down within a specific historical, geographical and chronological framework; it refers more to a group of individuals sharing common life experiences and perspectives than to proximity; it thus has to do with people that have experienced the same events, share more or less the same life contents, and partake into a common memory structure. The common historical, political and social space, background cultural institutions, explicit or implicit impressions and experiences within the same educational system "construct" a socially defined generational consciousness and identity (Schuman \& Scott, 1989). A generation shares common "sites of memory", lieux de mémoire (Nora, 1986). Conway (1997) contends that public events of an era instill a generation with common experiences toward a specific event, shared reactions to the same stimuli, collective existential problems and perceptions. Such things formulate and define an entire generation. Therefore, social memory and forgetting are filtered through the individuals' age. Generations and memories mutually construct each other, as a result of experiential communalities and similarities in the individual memories of social and historical events (Olick, 1999).

Many researches have shown that time reference to social events depends on the individuals' age: older individuals are those more likely to look for memories in their distant past (Auriat, 1996; Piolino, Desgranges \& Eustache, 2000; Lieury, 2005). The latter remark agrees with research findings on the time during an 
individual's development in which the social psychological identity emerges. Important social events taking place between the age of 12 and 25 endure in time and are considered as more important in an individual's life (Mannheim, 1928/1990; Pennebaker \& Banasik, 1997). During that, so called "critical period", individuals fall in love, establish and maintain close social bonds, develop friendships and interpersonal relationships. Overall, it is a period of intense emotional and even physiological diversity.

\section{Hypotheses}

The ability to retrieve an autobiographical event depends, among other things, on the characteristics of the event. Events linked to intense emotions, whether those are negative or positive, dominate memory (Auriat, 1996). Moreover, the individual remembers unusual events, events that happened for the first time in its lifetime (Auriat, 1996). Within this framework, we assume that the content of autobiographical memory and "oblivion" is composed by unique events, whether those are pretty and pleasant or ugly and unpleasant.

Also, a differentiation is to be expected among the three dimensions of autobiographical memory and "oblivion", namely the personal, family and social one. According to the platonic distinction between "oblivion medicine" and "oblivion poison", as suggested by Haas (2000), the content of personal and family "oblivion" will be composed by negative and traumatic events that upset the individual without degrading it or humiliating it (= oblivion "medicine"), whereas the content of social "oblivion" will be composed by negative and traumatic events, which are disgraceful, humiliating, forbidden or "silenced" (= oblivion "poison"), that is to say by events of "moral oblivion" (Ricoeur, 1999), which stigmatize and blot the individual's identity.

Lieury, Richer \& Weeger (1978) demonstrated that autobiographical events frequently interact with the public socio-political events. The latter function as points of reference for the autobiographical memories. Likewise, Brown \& Kulik (1977) indicated that an important and intensely emotional public event could affect the autobiographical memories of the individuals, who tend to link their personal experience to the public event. Schuman \& Scott (1989) denote that significant events of public character could have an effect on whole generations. Within this framework, it is expected that the participants will report among their personal autobiographical memories, events of public character.

The content of autobiographical memory and "oblivion" will depend on the age group that the participants belong to. The age groups have a common site of 
reference, unique to them, that emerges from their common experiences (Conway, 1997; Olick, 1999; Schuman \& Scott, 1989). Therefore, it is to be expected that individuals belonging to the same age group will report common events, which will differentiate them from other age groups. Furthermore, older individuals will refer to events reaching back to the distant past, compared to adults who will refer to the chronologically intermediate events and the younger individuals who will refer to the chronologically recent events. Finally, it was expected that the answers of men and women wouldn't differ, given that men and women participate in the same system of norms and values within their age group, as demonstrated in previous studies (Madoglou, 2005, 2010).

\section{Method}

Participants: 1210 male $(\mathrm{N}=575)$ and female $(\mathrm{N}=635)$ participants (aged $12-60+)$ completed an open-ended questionnaire. The samples were drawn from elementary school pupils, high school pupils, university students (random samples) and the general population (in the last case using a snowball technique). A detailed description of the sample is given in Table 1.

Table 1: Description of the sample according to gender, age-group and event type

\begin{tabular}{|l|l|c|c|c|c|c|c|c|c|c|}
\hline & & 12 yrs & 15 yrs & 17 yrs & $\begin{array}{c}18-24 \\
\text { yrs }\end{array}$ & $\begin{array}{c}30-45 \\
\text { yrs }\end{array}$ & $\begin{array}{c}46-59 \\
\text { yrs }\end{array}$ & $\begin{array}{c}60+ \\
\text { yrs }\end{array}$ & Total \\
\hline Family events & Male & 22 & 32 & 21 & 40 & 35 & 36 & 22 & 209 \\
\hline & Female & 23 & 28 & 27 & 57 & 45 & 41 & 29 & 249 \\
\hline
\end{tabular}

Design and measures: Approximately one-third of the participants $(N=458)$ were asked to write down three events concerning their family that they would want to remember (family voluntary memories) and three that they would like to forget (family involuntary memories). One-third of the participants $(\mathrm{N}=316)$ were asked to write down three events concerning their personal life that they would want to remember (personal voluntary memories) and three that they would like to forget (personal involuntary memories). The rest of the participants $(\mathrm{N}=436)$ were asked to write down three events that another person ("one") would want to 
remember ("social" voluntary memories) and three that he/she would like to forget ("social" involuntary memories). In addition, participants were asked to write down the year each of the events took place (only for personal and family memories).

608 Thus, the independent variables were: gender (male, female), age-group (12 yrs, $15 \mathrm{yrs}, 17 \mathrm{yrs}, 18-24 \mathrm{yrs}, 30-45 \mathrm{yrs}, 46-59 \mathrm{yrs}, 60+\mathrm{yrs}$ ), memory type (voluntary, involuntary), event type (family, personal, "social") and time the event took place. The dependent measures were the events described by participants and the year each of the events took place.

\section{Results}

\section{Objectification: Contents of voluntary and involuntary autobiogra- phical memories}

The contents of voluntary and involuntary memories -irrespective of type of event- are presented in Table 2. On the basis of their content, events were classified into broader categories. The percentage of participants who described a specific event is given in brackets.

The content of voluntary autobiographical memory is determined by events that belong to the following categories: family context (meeting spouse, wedding, marital life, child birth, birthday, etc.), friends (loved ones, friendship), love and sexual relationships (love affair, relationship), life stages (childhood, adolescence, "when young", school years, student life), job (job success, job established, retirement), material goods (material goods, lottery ticket, car purchase, house purchase, toy purchase, gift), studies (university, certificate, degree, etc.), leisure time (leisure time, outdoor games, football, etc.), happy moments (happy moments, happy circumstances, good things, etc.), health (cure), first time (experiences acquired for the first time in an individual's lifetime, such as first love affair, first love, first job, etc.), vacation and travels (school excursion, trip) and, finally, miscellaneous, where there are various answers not directly related to the content of autobiographical memory (everything, various, non-valid, don't remember). Under the same category of miscellaneous were classified the cases of individuals that did not give an answer (no answer) to any of the designated questions. 
Table 2: Contents of voluntary and involuntary memories

\begin{tabular}{|c|c|}
\hline Voluntary Memories (49.7\%) & Involuntary Memories (49.9\%) \\
\hline 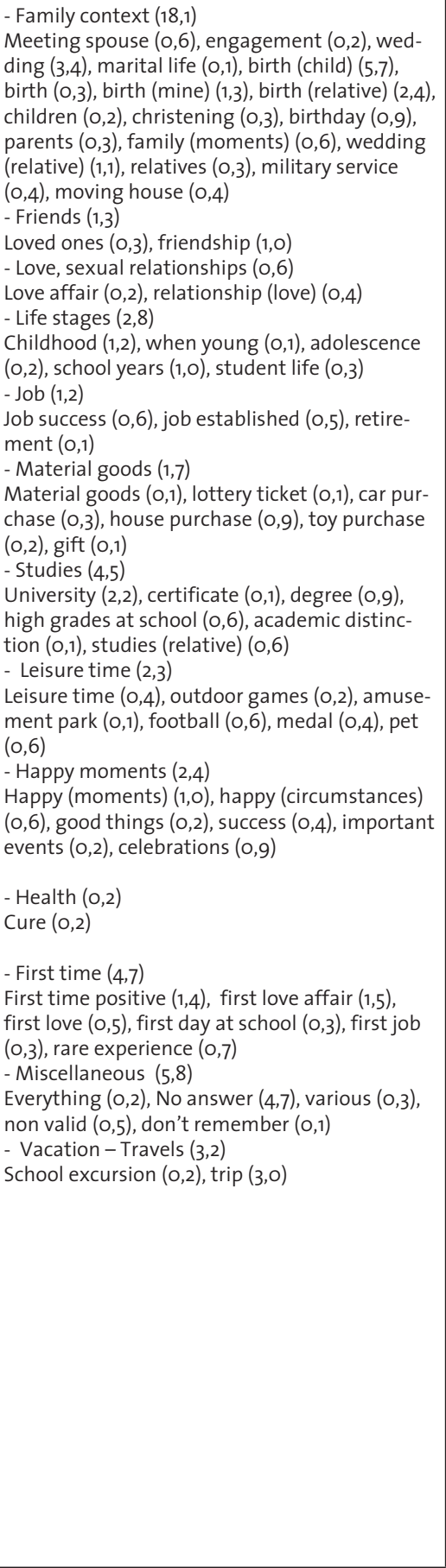 & 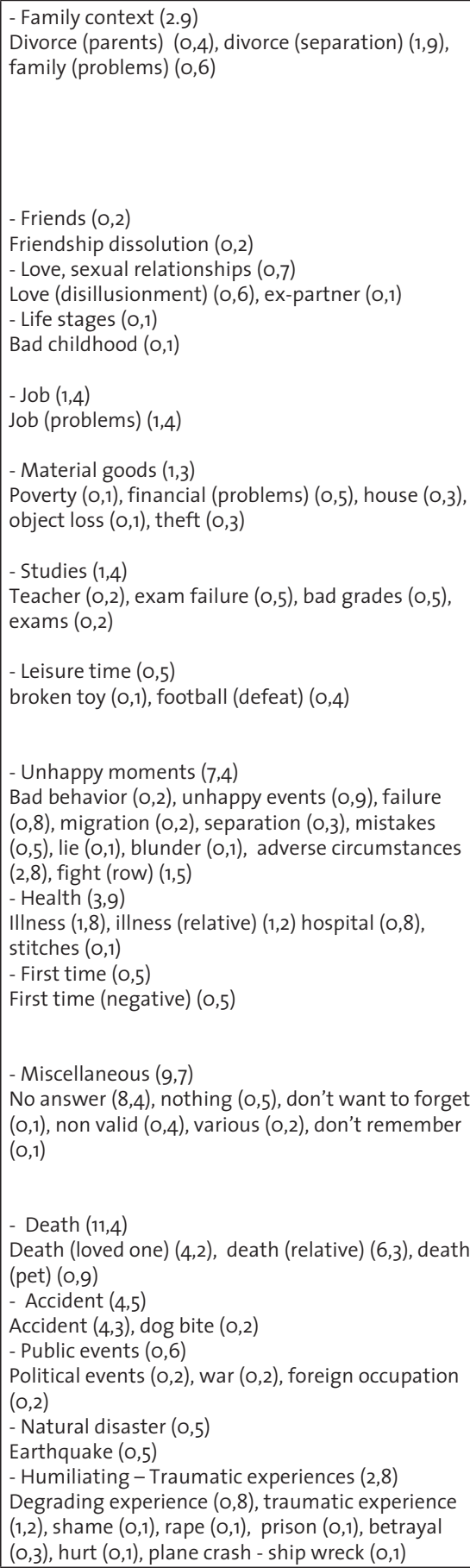 \\
\hline
\end{tabular}


As far as the content of involuntary autobiographical memory is concerned, it is linked to events that belong to the following categories: family context (divorceparent, divorce-separation, family problems), friends (friendship dissolution), love and sexual relationships (love disillusionment, ex-partner), life stages (bad childhood), job (job problems), materials-goods (poverty, financial problems, house, object loss, theft), studies (teacher, exam failure, bad grades, exams), leisure time (broken toy, football defeat), unhappy moments (bad behavior, unhappy events, failure, mistakes, etc.), health (illness, hospital, etc.), first time (negative experiences acquired for the first time).

The category vacation and travels is absent from the involuntary autobiographical memory, whereas we find five new categories. More specifically, the categories death (death of a loved one, death of a relative, death of a pet), accident (accident, dog bite), public events (political events, war, foreign occupation), natural disaster (earthquake) and humiliating and traumatic experiences (degrading experience, traumatic experience, shame, rape, prison, etc.) Finally, the category of miscellaneous includes various answers, such as "nothing", "don't want to forget", "various", "non valid", "don't remember", as well as the cases of individuals that didn't give an answer (no answer) to any of the three designated questions.

As we can see, voluntary and involuntary memories share a number of common themes. It is also worth noting that the "no answer" in the miscellaneous category is far more frequent $(8,4 \%)$ for involuntary memories than for voluntary memories $(4,7 \%)$ which may imply participants' difficulty or unwillingness to mention events leave in "silence".

\section{Anchoring: Memory contents in relation to gender, age-group, memory type (voluntary, involuntary) and event type (personal, family, social)}

Multiple correspondence analysis was selected in order to describe the ways memory contents might be differentiated depending on participants' gender, age-group, event type and memory type. The results of the multiple correspondence analysis are depicted in a two-dimensional space in Figure 1. The data set of the multiple correspondence analysis was also submitted to hierarchical cluster analysis the results of which are presented in Table 3 . 
The events of voluntary and involuntary autobiographical memories are classified under five characteristic groups. The first group corresponds to the social autobiographical memory of individuals aged 30-60+ years old and the main events mentioned by these individuals are wedding, degree, job success, child birth, job established, happy circumstances, love affair, happy moments, marital life, first love affair. Individuals aged 19-24 years old belong to the second group, who mention events of family autobiographical memory, namely the birth of a relative, trip, holidays, christening, studies of a relative, cure, house purchase, moving house, university, "everything". The personal autobiographical memory of individuals aged 12-17 years old is the characteristic of the third group and the most frequently mentioned events are a rare experience, first day at school, school years, "first time positive", birthday, high grades at school, leisure time, football, pet and medal. The fourth group expresses the social autobiographical "oblivion" of individuals aged 19-45 years old and the main events mentioned are the death of a loved one, job problems, adverse circumstances, traumatic experiences, divorce-separation, unhappy events, degrading experience, friendship dissolution, separation, illness. Finally, the fifth group is formed by individuals aged 12-15 years old, who mention events of family and personal autobiographical "oblivion", the most characteristic of which are fight, accident, death of a relative, hospital, home, family problems, earthquake, illness of a relative, nothing and no answer.

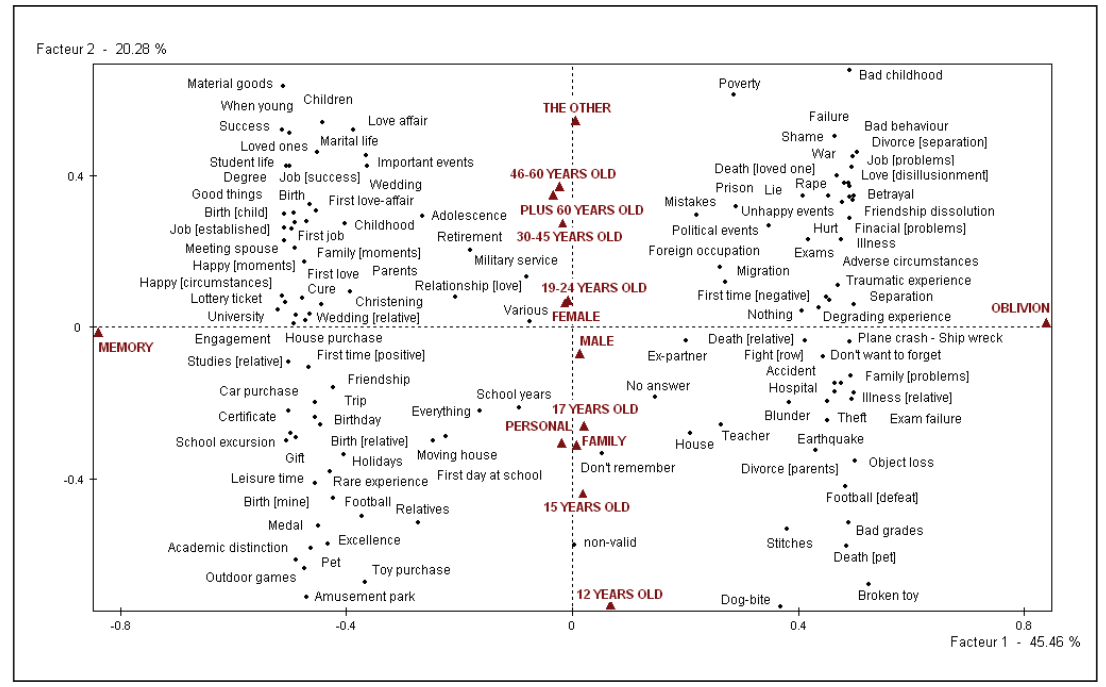

Figure 1: Memory contents in relation to gender, age-group, memory type and event type 
Table 3: Memory contents differentiating gender, age-groups, memory types and event types

\begin{tabular}{l|l}
\hline Categories & Memory contents \\
\hline $\begin{array}{l}\text { Social voluntary memories of } \\
\text { 30-45, 46-60 and 60+ year olds } \\
(20,33 \%)\end{array}$ & $\begin{array}{l}\text { Wedding, degree, job (success), birth (child), job } \\
\text { (established), happy (circumstances), love affair, happy } \\
\text { (moments), marital life, first love-affair }\end{array}$ \\
\hline $\begin{array}{l}\text { Family voluntary memories of } \\
\text { female, 19-24 years olds (14,37\%) }\end{array}$ & $\begin{array}{l}\text { Birth (relative), trip, holidays christening, } \\
\text { studies(relative), cure, house purchase, moving house, } \\
\text { university, everything }\end{array}$ \\
\hline $\begin{array}{l}\text { Personal voluntary memories } \\
\text { of male 12, 15 and 17 year olds } \\
(11,56 \%)\end{array}$ & $\begin{array}{l}\text { Rare experience, first day at school, school years, } \\
\text { first time (positive), birthday, high grades at school, } \\
\text { leisure time, football, pet, medal }\end{array}$ \\
\hline $\begin{array}{l}\text { Social involuntary memories } \\
\text { of 19-24 and 30-45 year olds } \\
\text { (20,59\%) }\end{array}$ & $\begin{array}{l}\text { Death (loved one), job (problems), } \\
\text { adverse circumstances, traumatic experiences, divorce } \\
\text { (separation), unhappy events, degrading experience, } \\
\text { friendship dissolution, separation, illness }\end{array}$ \\
\hline $\begin{array}{l}\text { Family and personal involuntary } \\
\text { memories of 12 and 15 year olds }\end{array}$ & $\begin{array}{l}\text { No answer, fight (row), accident, death (relative), } \\
\text { hospital, house, family (problems), earthquake, illness } \\
\text { (relative), nothing }\end{array}$ \\
\hline
\end{tabular}

\section{Social contexts: Time when described event took place in relation to gender, age-groups, memory type (voluntary, involuntary) and event type (personal, family)}

Multiple correspondence analysis was selected in order to describe the time the reported events took place. The time might be differentiated depending on participants' gender, age-group and event type (personal, family). The results of the multiple correspondence analysis are depicted in a two-dimensional space in Figure 2. On a first reading of the factorial diagram it can be observed that as the individuals grow older, the more the significant autobiographical events belong to the distant past reaching a date very far from today. 


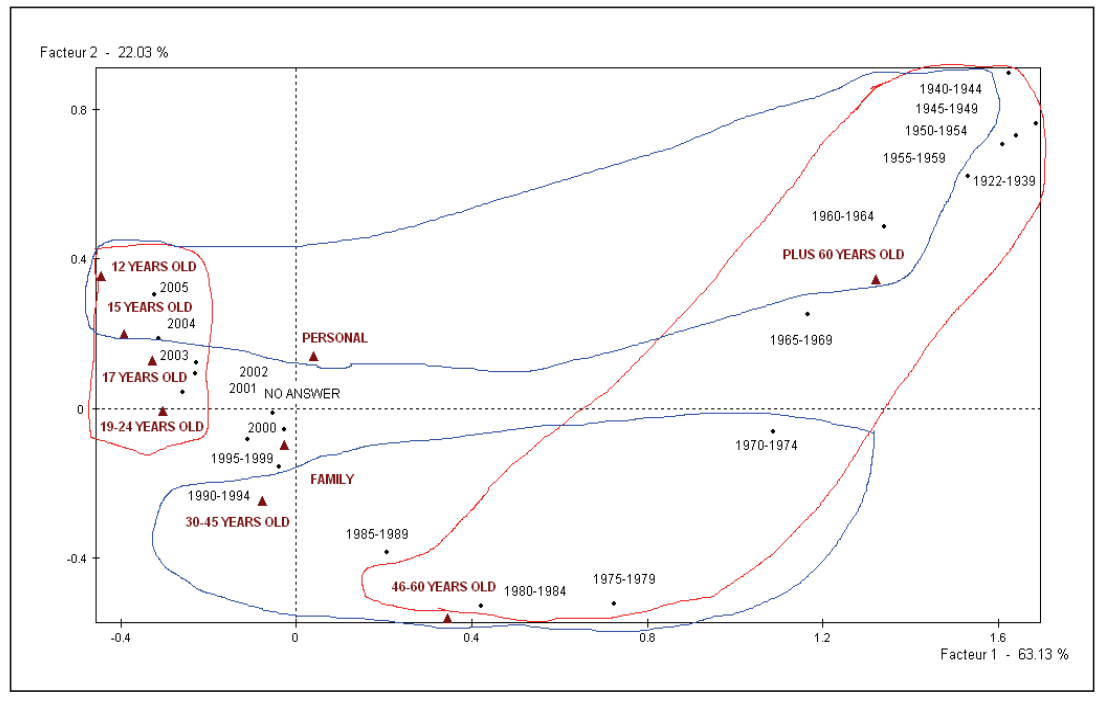

Figure 2: Time when described event took place in relation to age-groups and event type (personal, family²)

The hierarchical cluster analysis that was based on the factors presented in the multiple correspondence analysis, highlighted seven groups of events with the characteristics of the subjects and the conditions governing them. The results are presented analytically in Table 4.

The first group $(18,46 \%)$ is characterized by the personal memory of individuals aged 12-17 years old, that refer to events happening between 2002 and $2005^{3}$. Those events are a rare experience, birthday, happy circumstances, pet, trip, friendship, football, holidays, happy moments and a positive experience happening for the first time. The second group $(13,91 \%)$ is formed by individuals aged 19-24 years old, who focus on the family memory of the period 1980 to 2003 with reports, such as christening, birth of a relative, wedding of a relative, job success, cure, house purchase, car purchase, studies of a relative, relocation and family moments. 
Table 4: Voluntary and involuntary autobiographical memories (personal and family) in relation to age-group, sex and time context

\begin{tabular}{|c|c|}
\hline Categories & Memory contents \\
\hline $\begin{array}{l}\text { Personal voluntary memories of } \\
12,15,17 \text { year olds for the time } \\
\text { period } 2002-2005(18,46 \%)\end{array}$ & $\begin{array}{l}\text { Rare experience, birthday, happy (circumstances), pet, } \\
\text { trip, friendship, football, holidays, first time (positive), } \\
\text { happy (moments) }\end{array}$ \\
\hline $\begin{array}{l}\text { Family voluntary memories of } \\
\text { 19-24 year olds for periods 1980- } \\
1994,2001-2003(13,91 \%)\end{array}$ & $\begin{array}{l}\text { Christening, birth (relative), wedding (relative), job } \\
\text { (success), cure, house purchase, car purchase, studies } \\
\text { (relative), moving house, family (moments) }\end{array}$ \\
\hline $\begin{array}{l}\text { Voluntary memories of } 30-45 \\
46-60 \text { and } 60+\text { year olds for } \\
\text { periods } 1950-1989(10,20 \%)\end{array}$ & $\begin{array}{l}\text { Wedding, wedding (child), job (success), degree, } \\
\text { lottery ticket, marital life, meeting spouse, first job, } \\
\text { engagement, when young }\end{array}$ \\
\hline $\begin{array}{l}60+\text { year olds for periods } 1940- \\
1944(0,39 \%)\end{array}$ & Foreign occupation, poverty, war, prison \\
\hline $\begin{array}{l}60+\text { year olds for periods } 1940- \\
1974(0,28 \%)\end{array}$ & Political events, adolescences \\
\hline $\begin{array}{l}\text { Involuntary memories of } 19-24 \\
\text { year olds for periods } 1995-2005 \\
(36,55 \%)\end{array}$ & $\begin{array}{l}\text { Hospital, family (problems), accident, death (relative), } \\
\text { theft, fight (row), death (loved one), illness (relative), } \\
\text { illness, degrading experience }\end{array}$ \\
\hline $\begin{array}{l}\text { Family involuntary memories of } \\
17 \text { year olds for unspecified time } \\
\text { periods }(20,22 \%)\end{array}$ & $\begin{array}{l}\text { No answers, everything, nothing, don't remember, } \\
\text { non-valid, don't want to forget, good things, success, } \\
\text { important events, teacher }\end{array}$ \\
\hline
\end{tabular}

To the third group $(10,29 \%)$ pertain individuals aged $30-60+$ years old, who produce memory events of the period from 1950 to 1989. The events that had the largest contribution to the forming of this group are wedding, wedding of a child, job success, degree, lottery ticket, marital life, meeting spouse, first job, engagement, "when young". Individuals aged over 60 years old form the fourth group (o,39\%) and refer mainly to prison, occupation, poverty and the war of the period 1940-1944. Furthermore, individuals of the same generational identity (age group), that is to say over 60 years old, talk about their adolescence and political events, forming the fifth group $(0,28 \%)$. The sixth group $(36,55 \%)$ includes the oblivion of individuals aged 19-24 years old, which is related to events, such as hospital, family problems, accident, death of a relative, theft, fight, death of a loved one, illness of a relative, illness in general and the degrading experiences, that took place during the decade $1995-2005$. Finally, the seventh group $(20,22 \%)$ pertain individuals aged 17 years old, who refer to events of family oblivion without giving an answer to when the event actually took place: no answer, everything, nothing, don't remember, non-valid, don't want to forget, good things, successes, important events and teacher. 


\section{Discussion}

From the results of the study, a "good" memory and a "bad" oblivion were highlighted, which are connected to intense emotional experiences, unique and significant milestone events in the individuals' lives, unusual events, a rare experience and those which occurred for the "first time". The content of voluntary and involuntary autobiographical memory is objectified in the memories from family and school, childhood and adolescence, the student years, friendships, love and sexual relationships, professional life, vacations and travels, leisure time activities, special occasions, as well as health and material goods. Those events are present both in memory and oblivion composing the two sides of the same coin. Birth and death, health and sickness, success and failure, professional success or problems, wealth and poverty, happy and unhappy moments, traumatic or humiliating experiences, marriage, separation or divorce, friendships or relationships and fights, good childhood, adolescence and student years and the conflicts that arise are the same issues which constitute what we want to remember and what we want to forget. On the one hand, the desire and "obligation" for memory, on the other hand, the pain of remembrance and censorship of "oblivion", all of them accomplished with affection and strong emotions. Emotional experiences are separated in memory; either they contain an unpleasant or a pleasant content (Auriat, 1996).

Apart from the feelings, though, there are other characteristics of events that affect memory. Such a characteristic is the uniqueness of the event (Auriat, 1996). The individual remembers the unusual events, the events that happened for the first time in its life, whether those are positive or negative. The repeated events create a general memory and a difficulty in the memory recall. Therefore, it has been observed that the participants often mention unique events that have happened for the "first" time in their lives, such as the first sexual relationship, the first love disappointment, the first love, the first day at school, the first job, the first professional disappointment, the death of a parent, the birth of a child, a car accident or a serious illness. Those events that constitute a first or rare experience don't create general memories, but rather special ones, recorded in space-time context, due to the significance of their content and of the feelings they evoke. Those unique events function frequently as time reference points for the retrieval of other events (Halbwachs, 1925/1994. Ribot, 1881/2005). For example, an event happened before or after the event-point of reference, before or after marriage, the birth of a child, the death of a parent or the big earthquake.

Moreover, it has been ascertained that the experiences concerning the remembrance of a series of events regarding the same object are perceived as a whole, and the individuals better remember the beginning and the end of a series, that is to say the two extremes. They remember, for instance, the first day at school, 
their entrance in the university and the degree, whereas they talk about school and student years, having a general and overall memory. On one hand, they talk about how they met with their spouse, their marriage, the birth of a child and, on the other hand, about marital or family life.

The autobiographical events often interact with the public socio-political events (Lieury et al., 1978; Schuman and Scott, 1989; Brown and Kulik (1977). Within this framework, it has been accentuated that the participants report events of public character among their personal autobiographical memories. Those events of public character, such as various historical-political events (political events, war, foreign occupation), that are related to intense emotional moments and function as milestone events, facilitate the remembrance of autobiographical events that took place during the same period of time. The public events are inscribed in memory combined with the private/autobiographical events and vice versa, as it is underlined by Auriat (1996) and Schuman, Belli and Bischoping (1997).

Another important result of the present study concerns the distinction between "personal", "family" and "social" autobiographical memory and "oblivion", which was utilised in order to define mainly the "oblivion" of the autobiographical past. The results showed that autobiographical "oblivion" presents, on the one hand, a difficulty in referring to "oblivion" events (high percentages for the answers "nothing" and "no answer") which can be interpreted as "silences" and, on the other hand, references to events that the individual preferred not to have happened, because they are related to distressing situations accompanied by problems, conflicts, accidents, sickness, losses of loved ones, failures or a shipwreck, plane crash or earthquake. These events upset and scare the individual; however, they can be an issue for discussion, provided that they are not socially "forbidden". Nonetheless, there are also some traumatic and degrading experiences such as debasement, ridicule, humiliation, torture, maltreatment, violence, imprisonment, a bad sexual experience, rape, etc., which apart from being unpleasant situations, stigmatise the individual's existence. The latter compose "moral oblivion" (Ricoeur, 1999) and are set in silence because they refer to a socially "forbidden" truth. We can find these events in "social" autobiographical oblivion, where there is no personal involvement, when people don't talk about themselves or their family. Haas (2000) wonders if there is a good or bad "oblivion" and quotes the platonic distinction between "oblivion-medicine" and "oblivion-poison". The first one, which is life oriented, is an alleviating oblivion, which soothes despair, sorrows and sadness, whereas the second one is a type of "a-mnesiac" oblivion and concerns the denial of memory and of any mnemonic trace. Oblivion is a power that causes evil and at the same time it is a medicine for all evil things; it has a devastating and at the same time a beneficial effect. 
The content of autobiographical memory and "oblivion" passes through the age filter of individuals (Conway, 1997. Olick, 1999. Schuman \& Scott, 1989). The anchoring of auto-biographical memory events is determined by the individual's significant group affiliations. Therefore, kids aged 12-17 years old report events related to the companionship with their peers, the fights, school, football, medal, the relationship with a pet, and intra-familial issues (illness, death, et al.). The age 19-24 years old is related to events of family memory (birth, christening, house purchase, relocation, et al.) and with the student identity (university), which is considered a family matter. Nevertheless, along with the individuals aged 30-45 years old, they also refer to events of social autobiographical "oblivion", which are related to an illness or death, to job problems, to unpleasant, traumatic or degrading experiences, a divorce or separation. Finally, individuals aged over 30 years old report events of social memory regarding pleasant experiences, the sexual or conjugal relationship (first sexual relationship, erotic relationship, marriage, marital life, child birth) and the professional identity (degree, job established, job success). The results show that individuals of younger ages have a self-centered autobiographical memory, which, as time goes by, becomes more socio-centric. Other than that, it is observed that people of the same age group report common, yet distinctive, events that characterize their group. This means that the inclusion in a specific age group determines the selection of events which are significant for their identity. The aims, interests, activities, social and interpersonal relationships, benchmarks, the social context, social status quo, obligations, needs and employment issues are common in the same age group and different from those of the other groups.

Finally, no differences were observed in the answers provided by male and female participants. Men and women, pertaining in the same age group, participate in the same system of norms and values, as shown in previous studies (Madoglou, 2005, 2010, 2010a).

The autobiographical memories are composed both by events that cannot be determined through time and by events that have a specific date. The detection of a specific autobiographical event requires its social framework (spatial, time, affiliation groups...). The quality of autobiographical events depends on the generational effect and the same thing applies to their seniority. In addition, every age-group is characterized by the events which determine its generation identity. More specifically, individuals aged over 60 years old refer to socio-political events reaching back to the distant past, from 1940 to 1974 . Individuals aged 30-60+years old refer to memory events of the period from 1950 to 1989. The age they had during the above mentioned periods corresponds to a period of life rich in events and "first" memories (job, marriage, children...). Those events are milestones in an individual's lifetime, because they mark significant changes in its identity (degree, meeting of spouse, engagement, marriage, job established...). Kids aged 12-17 years 
old refer to the recent past of the period 2002 to 2005 reporting pleasant personal experiences, relationships with friends, trips and football. Individuals aged 19-24 years old focus on the family memory of the period 1980 to 2003 (christening, birth, marriage or studies of a relative, house or car purchase, relocation and family moments). They also refer to oblivion events of the period 1995 to 2005 (accident, death, illness, hospital, fights, theft and degrading experiences). The generation seems that it is not as much a biological phenomenon as it is, foremost, a social one. This is recorded in the answers that concern the quality of autobiographical events as well as their time frames.

\section{Conclusion}

The autobiographical memory concerns lived experiences, special to the individual, that determine its personal and social identity. Those experiences are limited in space and time and their content is constructed through everyday relationships that the individuals maintain with the members of the groups they belong to. Family, school, friends, professional space, the historical-social and political framework of their era provide them with existential milestones. The selection of past events is oriented by the way each individual is going to use them in the present. The purpose is to construct and defend their personal and social identity. Within this framework, in the representation constructed by the individual for its past, "the unpleasant characteristics are erased or diminished..." (Halbwachs (1925/1994, p. 112), distorted, change their meaning or are silenced.

The content of autobiographical memory consists of three "organizational principles" (Doise, 1989, 1992): a dominant memory, an oblivion-medicine and an oblivion-poison. The last one concerns the "memory of silent events" (Pennebaker \& Banasik, 1997), on which older people are mostly anchored to.

Memory functions are related to the construction and maintenance of the individual and social subject's identity, connecting it to the past and to its roots. Through the process of comparing to others, an individual's negative or positive past affects its self esteem. Memory provides the individual with a utilitarian and communicational argumentation, dictating and justifying its behaviors.

\section{References}

Abric, J.-C. (1994). L'organisation interne des représentations sociales: système central et système périphérique. In C. Guimelli (Ed), Structures et transformations des représentations sociales. Lausane : Delachaux et Niestlé, pp. 73-84. 
Abric, J.-C. \& Guimelli, C. (1998). Représentations sociales et effet de contexte. Connexions, 72, 23-37.

Augé, M. (1998). Les formes de l'oubli. Paris : Payot.

Auriat, N. (1996). Les défaillances de la mémoire humaine. Paris : Presses Universitaires de France, Institut National d'études démographiques.

Brown, M. \& Kulik, J. (1977). Flashbulb memories. Cognition, 5, 73-99.

Camilleri, C., Kastersztein, J., Lipiansky, E.-M., Malewska-Peyre, H., Taboada-Leonetti, I. \& Vasquez, A. (1990), (Eds). Stratégies identitaires. Paris : Presses Universitaires de France.

Candau, J. (1998). Mémoire et identité. Paris : Presses Universitaires de France.

Conway, M.A. (1997). The Inventory of Experience: Memory and Identity. In W.J. Pennebaker,

D. Paèz, B. Rime (Eds), Collective Memory of Political Events. New Jersey, Lawrence Erlbaum Associates Publishers, Mahwah, pp. 21-45.

Deschamps, J.-C., Paèz \& D., Pennebaker, J. (2001). Mémoire collective des événements sociopolitiques et culturels : représentations sociales du passé à la fin du millenium, Travaux sur la pensée sociale. Psychologie et Société, 3 (1), 53-74.

Deschamps, J.-C., Paèz, D., Pennebaker, J. (2002). Mémoire collective et histoire à la fin du second millénaire. In S Laurens, N. Roussiau (Eds), La mémoire sociale, Identités et Représentations Sociale. Rennes : Presses Universitaires, pp. 245-257.

Doise, W. (1989). Attitude et représentations sociales. In D. Jodelet (Ed.), Les représentations sociales. Paris : Presses Universitaires de France, pp. 220-238.

Doise, W. (1990). Les Représentations Sociales, In R. Ghiglione, C. Bonnet, J. F. Richard (Eds), Traité de Psychologie Cognitive, Tome 3: Cognitions, représentations, communication. Paris : Dunod, pp. 111-174.

Doise, W. (1992). L’ancrage dans les études sur les Représentations Sociales. Bulletin de Psychologie, XLV, 405, 189-195.

Doise, W. (2009). Discrimination sociales et droits universels, Itinéraires en psychologie sociale. Grenoble : Presses Universitaires de Grenoble.

Farr, R. (1984). Les représentations sociales. In S. Moscovici (Ed.), Psychologie Sociale. Paris: Presses Universitaires de France, 379-390.

Haas, V. \& Jodelet., D. (1999). Pensée et Mémoire sociale. In J.-P. Pétard (Ed.), Psychologie Sociale. Rosny, Bréal, pp. 111-160.

Haas, V. \& Jodelet, D. (2000). La Mémoire, ses aspects sociaux et collectifs. In N. Roussiau (Ed.), Psychologie sociale. Paris : In Press Éditions, pp. 121-134.

Haas, V. (2000). La " face cachée " de la mémoire, In M. Lavallée, S. Vincent, C. Ouellet, C. Garnier (Eds). Les représentations sociales, Constructions nouvelles, Montréal, GEIRSO, UQAM, 83-93.

Halbwachs, M. (1925/1994). Les cadres sociaux de la mémoire. Paris : Albin Michel.

Halbwachs, M. (1950/1968). La mémoire collective. Paris : Presses Universitaires de France.

Janet, P. (1928). L'Évolution de la mémoire et la notion du temps. Compte rendu intégral des conférences faites en 1928 au Collège de France. Paris : A. Chaline.

Jaisson, M. (1999). Temps et espace chez Maurice Halbwachs (1925-1945). Revue d'Histoire des Sciences Humaines, 1, 163-178.

Jodelet, D. (1992). Mémoire de masse: le côté morale et affectif de I’ histoire. Bulletin de psychologie, 405, XLV, 239-256.

Laurens, S. \& Roussiau, N. (2002), (Eds). La mémoire sociale, Identités et Représentations Sociales. Rennes : Presses Universitaires. 
Licata, L., Klein, O., \& Gély, R. (2007). Mémoire des conflits, conflits des mémoires : une approche psychosociale et philosophique du rôle de la mémoire collective dans les processus de réconciliation intergroupe. Sociale Science Information, 46, 4, 563-589.

Lieury, A. (2005). Psychologie de la mémoire. Histoire, théories, expériences. Paris : Dunod.

Lieury, A., Richer, E. \& Weeger, I. (1978). Les événements privés et publics dans les souvenirs. Bulletin de psychologie, 338, 41-48.

Lipiansky, E.-M. (1992). Identité et communication. Paris : Presses Universitaires de France.

Lyons, E. (1996). Coping with social change : Processes of social memory in the reconstruction of identities. In G.M. Breakwell, E. Lyons (Eds), Changing European Identities. Oxford : Butterworth-Heinemann, pp. 31-39.

Madoglou, A. (2005). Memories: Individual, Collective, Historical. Athens: Ellinika Grammata. (in Greek)

Madoglou, A. (2008). «Mnémostratégies vs Léthostratégies et le contenu de la mémoire individuelle volontaire et involontaire». Bulletin de Psychologie, 497, 61 (5), 431-448.

Madoglou, A. (2009). "Stratégies de représentations internes et externes de mémoire et d'oubli». Bulletin de Psychologie, 504, 62 (6), 515-531.

Madoglou, A. (2010). Social memory, social oblivion: explicit and implicit forms of social thought. Athens: Pedio. (in Greek)

Madoglou, A., Melista, A., Liaris-Hochhaus, S. (2010a). Greeks' and Germans' representations of world events: Selective memory and voluntary oblivion. Papers on Social Representations, 19 (2). http://www.psych.Ise.ac.uk/psr/.

Madoglou, A. (2011). Autobiographical memory and "oblivion" in personal, familial and social contexts. Hellenic Journal of Psychology, 8 (2), 193-228. (in Greek)

McLean, K.C., Pasupathi, M., \& Pals, J.L. (2007). Selves creating stories creating selves : A process model of self-development. Personality and Social Psychology Review, 11, 262-278.

Mannheim, K. (1928/1990). Le problème des générations. Paris : Nathan.

Middleton, D. \& Edwards, D. (1997). Conversational remembering: a social psychological approach. In D. Middleton, D. Edwards, (Eds), Collective Remembering. London : Sage Publications, pp. 23-45.

Moscovici, S. (1976). La Psychanalyse son image et son public. Paris : Presses Universitaires de France.

Moscovici, S. (1981). On Social representations. In : J. P. Forgas (Ed.), Social cognitions : perspectives on everyday understanding. Londres : Academic Press.

Nora, P. (1986). Les lieux de la mémoire. La nation. Paris: Gallimard.

Olick, J. K. (1999). Collective Memory: The two cultures. Sociological Theory, 17, 3, 333-348.

Pennebaker, W. J. \& Banasik, L. B. (1997). On the creation of collective Memories: History as Social Psychology. In W. J. Pennebaker, D. Paèz, B. Rime (Eds), Collective Memory of Political Events (pp. 3-19). New Jersey : Lawrence Erlbaum Associates, Publishers, Mahwah.

Piolino, P., Desgranges, B. \& Eustache, F. (2000). La mémoire autobiographique : Théorie et pratique. Solal Éditeurs.

Ribot, Th. (1881/2005). Les maladies de la mémoire. Paris : Marseille, L'Harmattan.

Ricoeur, P. (1999). A l'horizon de la prescription : l'oubli. Débat. In : Pourquoi se souvenir? (pp. 92-95). Colloque, Académie Universelle des Cultures. Paris : Grasset.

Rouquette, M.L. (1997). La Chasse à l'immigré. Violence, mémoire et représentations. Sprimont, Mardaga. 
Roussiau, N. \& Bonardi, Ch. (2002). Quelle place occupe la mémoire sociale dans le champ des représentations sociales. In : S. Laurens, N. Roussiau, (Eds), La mémoire collective, Identités et Représentations Sociales. Rennes : Presses Universitaires, pp. 33-49.

Rousso, H., (1999). Le statut de l'oubli. In : Pourquoi se souvenir? Colloque, Académie Universelle des Cultures. Paris : Grasset, pp. 109-112.

Schuman, H. \& Scott, J. (1989). Generations and collective memories. American Sociological Review, 54, 359-381.

Schuman, H., Belli, F.R. \& Bischoping, K. (1997). The Generational Basis of Historical Knowledge. In W. J. Pennebaker, D. Paèz, B. Rime (Eds), Collective Memory of Political Events. New Jersey : Lawrence Erlbaum Associates, Publishers, Mahwah, pp. 47-77.

Todorov, T. (2004). Les abus de la mémoire. Paris : Arléa.

Thadden, R. (1999). Une histoire, deux mémoires. In: Pourquoi se souvenir? Colloque, Académie Universelle des Cultures. Paris : Grasset, pp. 42-45.

Viaud, J. (2003). Mémoire collective, représentations sociales et pratiques. Connexions, 80, 13-30.

\section{Reconstruire des mémoires autobiographiques du présent: objectiva- tion, ancrage, effet de génération et cadres sociaux}

Le présent travail consiste à l'étude du contenu représentationnel de la mémoire autobiographique volontaire et involontaire (objectivation) et les ancrages selon l'age, le sexe et les cadres temporels. 1.200 participants de deux sexes et d'âges différents devaient écrire trois événements de mémoire et trois événements d' "oubli», dans un cadre personnel, familial et social et noter la date dont ces événements ont eu lieu. Les résultats révèlent la signification des cadres sociaux à la construction du passé autobiographique, qui sont l'espace, le temps et les différents groupes de références. Le contenu de la mémoire autobiographique se construit à travers les échanges quotidiens que les gens entretiennent avec les membres des groupes auxquels ils appartiennent. La famille, l'école, les fréquentations, le milieu professionnel, le cadre sociohistorique et politique de leur époque leur fournissent des références identitaires. La qualité et la datation des événements dépendent de la génération des questionnés.

MOTS-CLÉS: Mémoire autobiographique, Mémoire sociale et oubli social, Représentations sociales, Cadres temporels, Effet de génération 